\title{
Future sustainability scenarios for universities: moving beyond the United Nations Decade of Education for Sustainable Development
}

\author{
Ali Beynaghi a, b, c, *, Gregory Trencher ${ }^{\mathrm{d}}$, Fathollah Moztarzadeh ${ }^{\mathrm{a}}$, Masoud Mozafari e, Reza \\ Maknoon ${ }^{\mathrm{b}}$, Walter Leal Filho ${ }^{\mathrm{f}, * *}$ \\ a Technology Foresight Group, Department of Management, Science and Technology, Amirkabir University of Technology, Tehran, Iran b Office of \\ Sustainability, Amirkabir University of Technology, Tehran, Iran c Futures Studies Research Institute, Amirkabir University of Technology, Tehran, \\ Iran \\ d Clark University, Department of International Development, Community, and Environment, Massachusetts, USA e \\ Nanotechnology and Advanced Materials Department, Materials and Energy Research Center (MERC), Tehran, Iran f School of \\ Sciences and the Environment, Manchester Metropolitan University, UK
}

Keywords:

Sustainable development

Higher education

United Nations Decade of Education for

Sustainable Development

Education for Sustainable Development abstract

As achievements of the completed United Nations Decade (2005e2014) of Education for Sustainable Development are contemplated globally, along with potential steps forward for the future, Member States have urged that this decade continue after 2014 through "The Future We Want"; the outcome document of the 2012 United Nations Conference on Sustainable Development. More recently, commitments to furthering the advancement of sustainable development through education have also been re-enforced in the recently adopted post-2015 Sustainable Development Goals. This study systematically

\section{Introduction}

Higher education is one of the most significant indicators of global competitiveness (Schwab, 2013). In response to globalization and the so-called "knowledge economy", many countries have attempted to improve international competitiveness by developing and modifying macro policies for strengthening higher education, and particularly universitiesda core component of the education sector (Ritzen, 2006). In this context, many researchers have attempted to propose different perspectives for envisioning future universities using various futures studies methods such as trend analysis (Boer et al., 2002; Stephens, 2013), causal layered analysis (Inayatullah and Milojevic, 2014; Zepke, 2012), Delphi study (Hayes, 2007), and scenario development (Inayatullah, 2012; Job and Sriraman, 2013). Although such studies do not explore future university visions with regard to sustainability, they are driven by assumptions that, being a "living institution" with nearly 1000 years of history (Ford, 2002; Martin, 2012), the university is constantly evolving in response to the changing demands of society and key stakeholders. From such a perspective, it is reasonable to assume that the university will continue to transform and adapt its structure, functions and governance in accord with the changing social, environmental and economic challenges of this century.

Building upon a combination of various futures studies methods, this study aimed to systematically analyze the implications of sustainable development trends and future directions universities might take under a potential second decade (2015e2024). It accomplished this by developing and applying a model for creating "trend-based scenarios". This allowed the authors to consider how evolving trends related to the higher education landscape and conceptions of sustainable development are merging to influence the way universities integrate sustainability into missions, structures and activities. The underlying assumption of the analysis model proposed herein is that a possible, probable or preferable space of the future can be identified from the intersection of several trends. Consideration of the future forms, functions and characteristics that the university might take over the next decade would be useful for two reasons. Firstly, it would allow better understanding into present changes and the key 
driving forces behind these. Secondly, by considering various trajectories that a potential second ten-year commitment to sustainable development might trigger, this foresight and visioning exercise allows simultaneously insight into the types of policies and conditions required to support any of these future possibilities. By exploring three potential pathways the university might integrate sustainability a decade from now, this study bridges and contributes to three bodies of literature, that until now, have not been treated in parallel. That is, futures studies and scenario development, sustainable development in higher education, and the broader field of higher education research itself.

This paper is structured as follows. The following section briefly analyzes the literature on the application of scenario development for the future of higher education and then provides an overview of the emergence of sustainable development in higher education. Section three is given to explaining the methodological dimensions of this study and the process by which the three future models of university were arrived at. Section four presents our findings, and in particular, three scenarios and contrasting models of university that the authors perceive to be likely pathways that the university might take over the next decade in response to a second UN DESD and greater efforts to advance societal sustainability. Then, in section five the authors consider various external and internal policy and incentive measures that might encourage a university to head toward any of these futures. The final section presents some concluding remarks and underlines the potential utility of our study, together with some potential directions for future research. 2. Theoretical perspectives

Scenarios are usually used to describe future situations foreseen as consequences of potential policy decisions (Amer et al., 2013). Although scenarios cannot represent all the complexities of world events and provide a completely accurate picture of the future, they can help policy makers to consider the uncertainties that they are likely to face (O'Brien, 2004). The emergence of scenario development dates back to military strategic studies (Kahn et al., 1967) and in particular to the U.S. Department of Defense, which during the 1950s at RAND Corporation ${ }^{1}$ systematically used a scenario building methodology about the future (Borjeson et al., 2006€). From the 1960s, this methodology has since been widely used for social forecasting, public policy analysis and decision making (Bradfield et al., 2005). Yet it has also been introduced into the economic milieu since the $1970 \mathrm{~s}$, notably through integration into the corporate management planning processes by Royal Dutch Shell (Bishop et al., 2007). The Club of Rome's "Limits to Growth" (Meadows, 1972) is probably the best known scenario study and also one of the most controversial. Nowadays, scenarios are drawn up for local, regional and global issues by the most diverse protagonists and companies of all sizes (Varum and Melo, 2010).

There are countless ways to categorize different types of scenarios. Firstly, they may be categorized as being either descriptive (forecasting) or normative (backcasting) (Van Notten et al., 2003). Descriptive scenarios are extrapolative in nature and offer a range of alternative images for the future. Normative scenarios are goal directed and respond to policy planning concerns for achieving desired targets. Scenarios may also be classified in accord with other variables such as the scenario topic (i.e. problem-specific verses broader global scenarios), the breadth of the scenario scope (i.e. one sector verses multi-sector scenarios), the paths of change explored (i.e. environmental transformations verses policy scenarios), and finally, the level of aggregation (i.e. micro verses macro scenarios) (Amer et al., 2013). The literature indicates that scenario building techniques have evolved into a futures research paradigm from predominantly quantitative approaches toward a more qualitative and process-oriented approach (Ramirez et al., 2015; Swart et al., 2004). Quantitative methods appear suited to narrowly focused subjects with a shorttime horizon, whilst on the other hand, their usefulness declines steadily as the timeframe examined extends further into the future (Nowack et al., 2011). In contrast, qualitative approaches generally appear more suited to subjects having a wider scope, both temporally and physically, and their utility increases the further one glances into the future.
Qualitative methods have evolved into a set of very complex sub-techniques, typically with the help of an expert panel or sophisticated software tools (Bishop et al., 2007; Fink et al., 2004). Many authorities believe that scenario development in combination with other futures studies methods, such as trend analysis, can serve as a powerful tool for exploring future developments in science, technology and society (Pillkahn, 2008). Since these type of scenarios usually consider the past to be a model for the future, they are called trend-based (Hughes, 2013). Accordingly, in such scenarios existing trends are projected into the future; generally with a high and low extreme value, and one or more middle values.

Turning now to the field of higher education, and in particular to universities, different studies have attempted to systematically articulate scenarios for the future of higher education, each with distinct approaches. Table 1 illustrates the results of analyzing key research in this field. This table is categorized into the type of publication (report, book or academic articles); scope of survey (individual institution, national or global level) and the main focus (theme) of the research. As shown in this table, a survey of the related literature reveals a number of important and 
Table 1

Summary of analysis on key studies exploring future scenarios for universities.

\begin{tabular}{|c|c|c|c|}
\hline Author(s) & Format & Scope of survey & Main focus \\
\hline McNay (1992) & Book & Global & $\begin{array}{l}\text { Diversity and equity, individual and collective identity, freedom and trust, } \\
\text { collaboration and community commitment }\end{array}$ \\
\hline Conway (2003) & Article & Individual institution & $\begin{array}{l}\text { Education, societal values and expectations, local demographic issues, globalization, information technology, } \\
\text { financial issues and market needs, environmental issues, government policy }\end{array}$ \\
\hline Miller (2003) & Report & OECD countries & Lifelong learning, networking, diversity, tradition and entrepreneurship \\
\hline Vincent-Lancrin (2004) & Article & OECD countries & Tradition, entrepreneurship, the market, lifelong learning, networks and diversity of learning \\
\hline Avila and Leger (2005) & Book & Global & Politics, the labor market, the value of education, social demands, and quality \\
\hline $\begin{array}{c}\text { Hashimshony and } \\
\text { Haina (2006) }\end{array}$ & Article & Global & Physical and organizational structures of universities \\
\hline Ritzen (2006) & Article & Global & Demand for higher education: international talents, lifelong learning \\
\hline Snyder (2006) & Article & Global & Time in education, fuller education and further education \\
\hline Vincent-Lancrin (2006) & Article & OECD countries & Funding, administration and market force, national and international trends \\
\hline $\begin{array}{l}\text { Amatariyakul and Tesaputa } \\
\text { (2009) }\end{array}$ & Article & Individual institution & Learning and teaching management, research, academic services, art and cultural maintenance \\
\hline Azman et al. (2010) & Article & National (Malaysia) & Economic drivers, democratization of knowledge, corporatization and the learning environment \\
\hline Blass et al. (2010) & Article & National (UK) & $\begin{array}{l}\text { Globalization and international students, demographic trends and non-traditional students, } \\
\text { digitalization, democratization }\end{array}$ \\
\hline Barth et al. (2011) & Article & Global & Sustainable universities \\
\hline Stephens (2011) & Article & National (Ireland) & Access, curriculum, management, external environment and assessment \\
\hline Duderstadt (2012) & Article & Global & $\begin{array}{l}\text { Knowledge economy, diversity, technological change, globalization, demographic change, } \\
\text { global sustainability, lifelong learning, market, access }\end{array}$ \\
\hline Inayatullah (2012) & Article & Asian-Pacific countries & Globalization, Virtualization, democratization, multiculturalism \\
\hline Inayatullah et al. (2013) & Article & Individual institution & Curriculum, learning process, technological change, organizational structure, leadership, campus \\
\hline Nasruddin et al. (2012) & Article & Individual institution & Intellectual freedom, learning environment \\
\hline
\end{tabular}

recurring drivers in discussions on the future of higher education. These include globalization, information and communication technology (ICT) and virtualization, demographic changes, time spent in education, access, teaching, funding, institutional design, the student experience, and the knowledge economy. As a further observation, although scenario-based planning is widely practiced at the level of individual corporations, military and governments (Wilkinson and Kupers, 2013), our review of the literature shows that most studies in industrialized economies are focused on clusters of universities in countries, regions or the globe as a whole. Bar a few studies in younger institutions in emerging Asian economies such as Universiti Sains Malaysia (Nasruddin et al., 2012), BRAC University in BRAC in Bangladesh (Inayatullah et al., 2013), and Rajamangala University of Technology Isan in Thailand (Amatariyakul and Tesaputa, 2009) and Swinburne University of Technology in Australia (Conway, 2003), we found little published evidence to suggest that individual universities around the world are widely using strategic backcasting and planning based upon future scenarios. Furthermore, it is highly unclear if the foresight and scenario-based planning initiatives showcased in these studies have actually served to influence administrative or faculty decision making, and if concrete steps have been made towards any desirable scenario identified. However, one commonality across these initiatives is clear. Scenario planning is highly participative and can potentially involve large numbers of actors from across administrative and academic quarters of the university. As a final and noteworthy observation on this examined literature as a whole, with the exception of Barth et al. (2011), Table 1 shows that studies examining the potential future effects of sustainable development trends on the higher education landscape are largely absent. It is this last gap in particular that this study has thereby attempted to fill.

Outside of the futures studies field, the challenge of sustainable development has emerged as a major global trend affecting the higher education landscape (DiSano, 1999). This has prompted the formation of a still evolving field of scholarship. Non-exhaustively, studies have been conducted from various dimensions and higher education functions such as campuses and operations, curriculums and education (Leal Filho et al., 2015a; Wals, 2014) and research (Waas et al., 2010; Yarime et al., 2012). More recently, interest is growing around university linkages with society and the ability of universities to collaborate with external stakeholders to transform their surrounding communities and regions (Trencher et al., 2014a, 2014b;
Zilahy and Huisingh, 2009). Increasing tendencies to collaborate with society in knowledge production have also prompted experiential and collaborative forms of sustainability education in tandem with societal stakeholders (Trencher et al., 2016). Of importance, the effectiveness of collaborative and real-world learning approaches to sustainability education has been recently highlighted and promoted by the United Nations Decade of Education for Sustainable Development (UN DESD) (Tilbury, 2011) and other scholars (Leal Filho and Brandli, 2016).

With the emergence of sustainable development largely attributable to the first United Nations Conference on the Human Environment (UNCHE) in Stockholm, Sweden in 1972, this concept has since evolved into a guiding paradigm for development and diverse areas of human activity in the twentieth century. The United Nations General Assembly adopted the DESD for the period 2005 to 2014, designating the United Nations Educational, Scientific and Cultural Organization (UNESCO) as the lead agency to guide various global education programs to emphasize the critical role of education in pursuing sustainable development (UNESCO, 2005a, 2005b). Throughout this decade, various global, national, regional and local efforts were made to advance progress to a more sustainable world through different forms of education, public awareness and training activities (Pigozzi, 2010; Tilbury, 2009). Although the decade has come to an end in 2014 leaving an array of unresolved questions regarding impacts achieved (Leal Filho, 2014; Leal Filho et al., 2015b; Wals, 2014), in the outcome document of the 2012 UN Conference on Sustainable Development (Riop20), "The Future We Want" (United Nations, 2012), Member States have committed to strengthening Education for Sustainable Development (ESD) beyond the end of the UN DESD:

"We resolve to promote education for sustainable development and to integrate sustainable development more actively into education beyond the United Nations Decade of Education for Sustainable Development." (United Nations, 2012, Par 233)

This commitment to continuing ESD has since been reinforced in Goal 4 of the emerging post-2015 Sustainable Development Goals (SDGs) in the outcome document "Transforming our world: the 2030 Agenda for Sustainable Development" (UN, 2015).

In considering possible future directions for a potential second decade UN DESD (2015e2024), the field of sustainability science illustrates that futures studies methods, especially scenario development, have much relevance to the 
societal pursuit of sustainable development (de Vries and Petersen, 2009; Phdungsilp, 2011; Wangel, 2011). Since a wide spectrum of issues in the field of sustainability research demand consideration of complex systems and their dynamic interaction (Kates et al., 2001), qualitative scenario methods appear well-suited to the analysis of sustainably related matters (Barth et al., 2011). This justifies our choice to apply such qualitative future scenario making approaches to the study of the university in the specific context of sustainable development, and in particular, the decade following the closure of the UN DESD.

\section{Methods: overview of approach}

Based on insights from the above-described literature, the following sections outline a new scenario development model

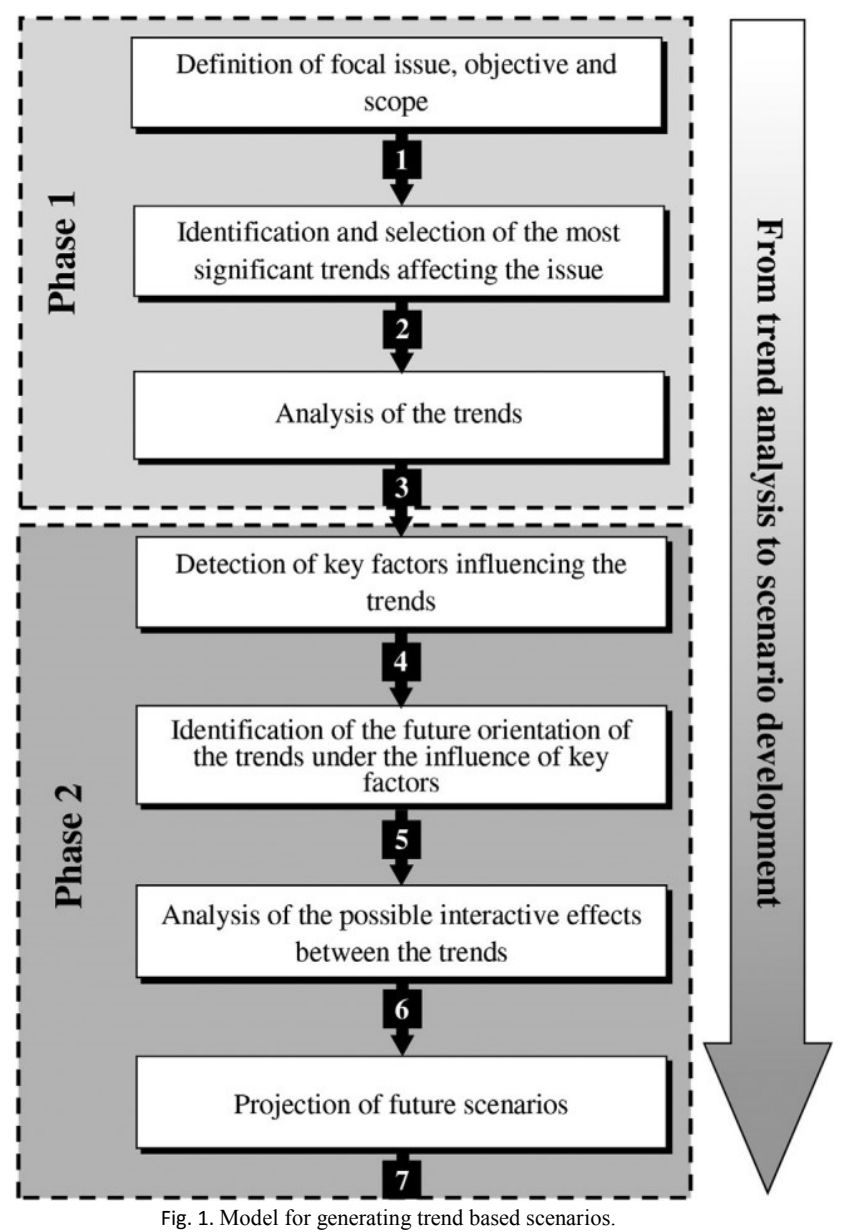

Technology (AUT), held in Tehran in December 2013. This panel convened several international experts (n 1/4 15) with differing scientific backgrounds and breadth of professional experience 2 related to the subject of "sustainability in higher education". In the first hour, to facilitate a common understanding of the subject at stake, discussions concentrated on deliberation of the results obtained from the first phase. The final four hours then revolved around considerations of how these trends would develop over the next decade and the question of how a second UN DESD (i.e. 2015e2024) could possibly affect the future orientation of universities during this period, from a global perspective. Panelists also aimed to reach the most reliable consensus of opinion among the differing members through collaborative brainstorming and discussion. Each step of the tool depicted in Fig. 1 is described below. that the authors propose for systematically analyzing future models of the university that might arise in accord with future trends related to sustainable development and ESD. As shown in Fig. 1, this tool identifies possible, probable or preferred spaces of the future from the intersection of different trends, based upon two interrelated phases. For the first three steps comprising the first phase, by examining various key literature related to i) higher education, ii) sustainable development and iii) sustainable development in higher education, the authors have identified some key trends and developments impacting universities in different ways. Stretching from pre1950s and continuing until the present, some of these trends are collated in Fig. 2 and explained in detail as findings in Sections 4.1.1 to 4.1.3. The "inputs" for the second phase, in turn, have derived from the identification and analysis of these trends. Here a special emphasis was given to the extent to which they may influence the higher education landscape and conceptions of sustainable development, as well as the interactions between these two.

Fig. 1 shows that the second phase concerns the detection of the most important factors influencing these two trends. It involves the examination of how these factors might influence future trajectories, and finally, the creation of scenarios based showing the interactions between trends.

In carrying out the second phase, this study draws upon results of an expert panel discussion. Using outputs from the first phase, this panel took place at "The Second Conference on Sustainability and Higher Education", organised by the Futures Studies Research Institute and Office of Sustainability at Amirkabir University of

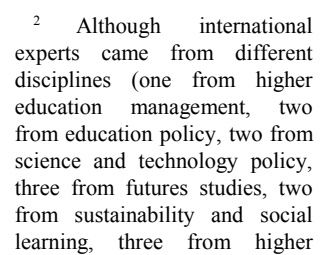

different disciplines (one from higher education management, two science and technology policy, three from futures studies, two
from sustainability and social learning, three from higher education development planning, one from sustainability and environmental planning, one from sociology of education), they were chosen purposively for their strong interest and knowledge in "sustainability in higher education". 


\subsection{First step: definition of focal issue, objective and scope}

This setting step determines the range of issues to be taken into account by considering an appropriate time-horizon and a clear, specific purpose. In the context of our approach, scenarios are not considered as a forecast or precise prediction, nor do they state a desirable picture of the future. Rather they produce a picture or a story describing a possible future for an emerging new paradigm shift within universities around the world. For this study, the main purpose is to identify and assess future perspective of universities, in a medium term (10 years) under the influence of sustainable development.

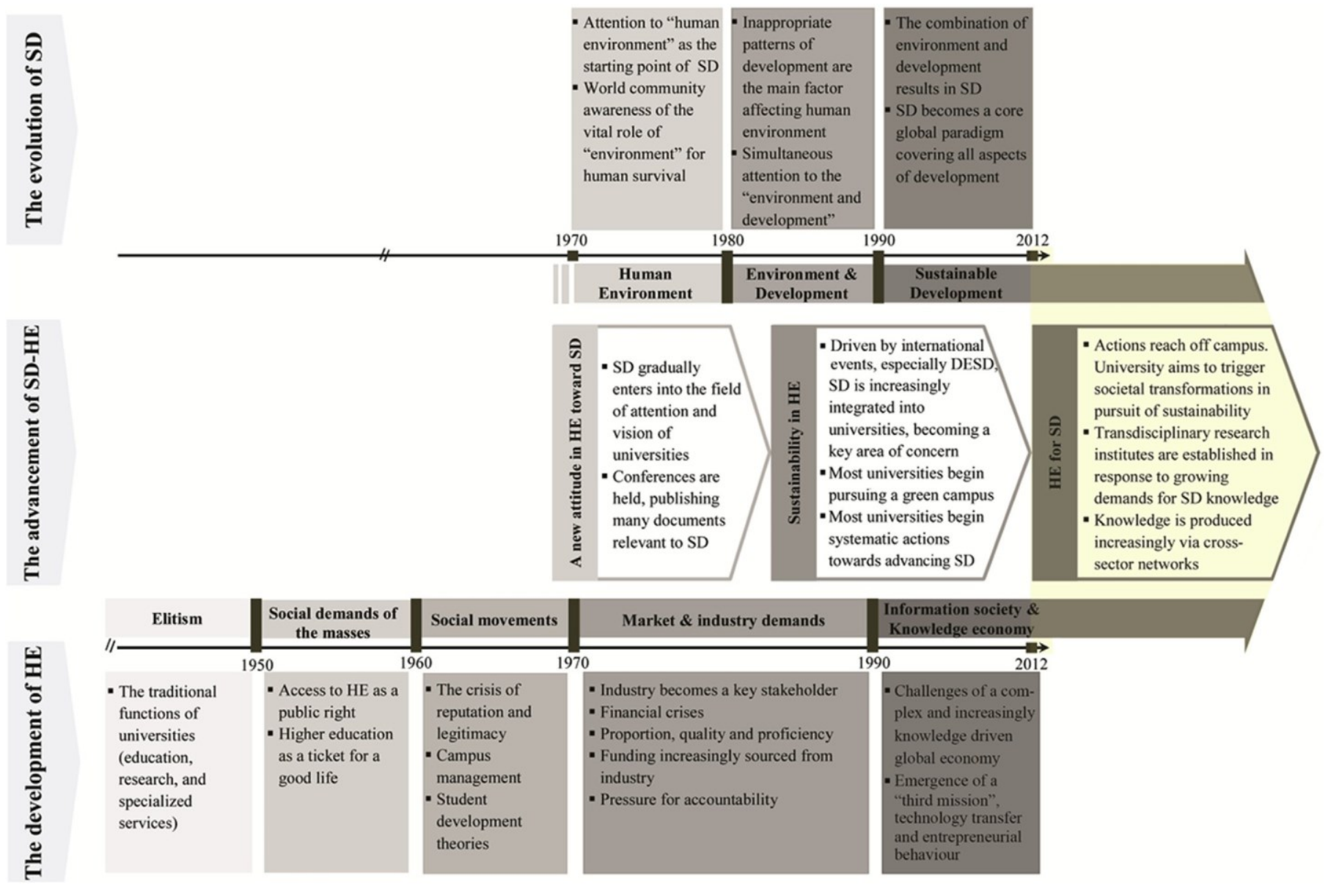

Fig. 2. The combination of "HE", "SD" and "the nexus between $\mathrm{SD}$ and $\mathrm{HE}$ " trends from a qualitative trend analysis.

3.2. Second step: identification and selection of the most significant trends affecting the issue

The second step addresses the question: What are important trends and critical uncertainties that will potentially impact on the future of the main issue? Trends are the factors which have a comparatively high impact and are simultaneously relatively predictable. They become important for the description of scenarios in the following steps of the scenario-based approach. Although different macro trends such as technology, demographic changes, culture, globalization, knowledge economy and politics will impact on the future orientation of universities, this research aims to specifically explore the implications of sustainable development as a major global trend for the future orientation of universities. Therefore, SD, HE, and SD-HE are considered as three qualitative trends in this study.

\subsection{Third step: analysis of the trends}

This step provides a breeding ground to effectively monitor changes in chosen qualitative trends, from the past into the present, focusing on the cumulative tendency of the change in any specified period of time generated by significant events. In essence, this step aims to observe and register the past performance of the trends relying on a qualitative trend analysis.

In this study, considering SD, HE, and SD-HE as three qualitative trends, several unique events related to these trends such as international conferences and summits, declarations, charters and initiatives are identified during this step (Table 2). The authors have highlighted key changes in these trends through a content analysis of outcome documents from these events, along with several papers published between 2000 and 2014 within leading journals 
actively covering the field of sustainable development, higher education, or both.

\subsection{Fourth step: detection of key factors influencing the trends}

In this step, key factors or driving forces that could shape the focal issue in both predictable and unpredictable ways are explored. Driving forces include factors affecting immediate working environments (like developments related to one's community) and broader shifts in the social, technological, economic, environmental, and political environment. Driving forces can be either "predetermined elements" or "uncertainties" (Scearce et al., 2004). Predetermined elements are forces of change that are relatively certain over a given future timeframe, such as a locked-in degree of income disparity, predictable cuts in public spending, or a foreseeable shift in demographics. Uncertainties are unpredictable driving forces, such as the nature of public opinion or shifts in social values.

Table 2

The most widely recognized international events related to SD, HE, and SD-HE. Adapted and updated from (Leal Filho, 2011b; Lozano et al., 2013a).

\begin{tabular}{|c|c|}
\hline Year & Event \\
\hline 1972 & $\begin{array}{l}\text { United Nations Conference on the Human } \\
\text { Environment (UNCHE), Sweden }\end{array}$ \\
\hline 1975 & $\begin{array}{l}\text { The Belgrade Charter, Belgrade Conference on } \\
\text { Environmental Education, Yugoslavia }\end{array}$ \\
\hline 1977 & $\begin{array}{l}\text { Tbilisi Declaration, Intergovernmental Conference on } \\
\text { Environmental Education, Georgia }\end{array}$ \\
\hline 1987 & "Our Common Future", The Brundtland Report \\
\hline 1990 & Talloires Declaration, Presidents Conference, France \\
\hline 1991 & $\begin{array}{l}\text { Halifax Declaration, Conference on University Action for } \\
\text { Sustainable Development, Canada }\end{array}$ \\
\hline 1992 & $\begin{array}{l}\text { UN Conference on Environment and } \\
\text { Development (Rio Conference), Brazil }\end{array}$ \\
\hline 1993 & $\begin{array}{l}\text { Kyoto Declaration, International Association of } \\
\text { Universities Ninth Round Table, Japan }\end{array}$ \\
\hline 1993 & $\begin{array}{l}\text { Swansea Declaration, Association of Commonwealth } \\
\text { Universities' Fifteenth Quinquennial Conference, Wales }\end{array}$ \\
\hline 1993 & $\begin{array}{l}\text { COPERNICUS University Charter, Conference of } \\
\text { European Rectors (CRE) }\end{array}$ \\
\hline 2000 & Millennium Development Goals \\
\hline 2001 & $\begin{array}{l}\text { Lüneburg Declaration on Higher Education for } \\
\text { Sustainable Development, Germany }\end{array}$ \\
\hline 2002 & $\begin{array}{l}\text { World Summit on Sustainable Development (WSSD) in } \\
\text { Johannesburg, South Africa }\end{array}$ \\
\hline 2004 & Declaration of Barcelona \\
\hline 2005 & $\begin{array}{l}\text { Start of the UN Decade of Education for } \\
\text { Sustainable Development (UN DESD) }\end{array}$ \\
\hline 2005 & $\begin{array}{l}\text { Graz Declaration on Committing Universities to } \\
\text { Sustainable Development, Austria }\end{array}$ \\
\hline 2009 & $\begin{array}{l}\text { Abuja Declaration on Sustainable Development in Africa: The role of } \\
\text { higher education in SD, Nigeria }\end{array}$ \\
\hline 2009 & $\begin{array}{l}\text { Torino (Turin) Declaration on Education and Research for } \\
\text { Sustainable and Responsible Development, Italy }\end{array}$ \\
\hline 2012 & Riop20 Treaty on Higher Education \\
\hline 2012 & UN Conference on Sustainable Development (Riop20), Brazil \\
\hline
\end{tabular}

In this study, in addition to these broader societal trends, emphasis was given to Riop20 and its outcome document "The Future We Want" (United Nations, 2012). Also relevant are the more recently stated UN member state commitments in the post2015 SDGs (United Nations, 2015) to the continued pursuit of sustainable development through education, as these international agreements will significantly affect key trends impacting higher education in the next decade 2015e2024. Incidentally, at the time of the expert panel discussion in December 2013, debates about Post-2015 SDGs were still underdeveloped. Since Riop20 and "The Future We Want" were more influential in discussions about a potential second decade UN DESD (2015e2024), this was considered as a key factor that would affect future sustainability scenarios for universities. By positioning education, and particularly universities, as a key driver for achieving sustainable development, the Future We Want agreement outlines at item 233 a resolve to "promote Education for Sustainable Development and to integrate sustainable development more actively into education beyond the United Nations Decade of Education for Sustainable Development (2005e2014)". In applying this step, the authors have paid special attention to how these signaled commitments to continued integration of sustainable development in higher education might affect SD, SD-HE, and finally HE, the three variables in question.

3.5. Fifth step: identification of the future orientation of the trends under the influence of key factors

In conventional trend-based scenarios, future orientation of trends is based on simple causalities and merely extrapolating the historical and current path directly into the future. Since they ignore the possible effects of external factors on transformation of trends, they are often unable to deal with uncertainties in a complex, future world. Cognizant of this weakness, this proposed scenario development attempts to identify possible influential factors on the future orientation of the trends in question (as in the fourth step), and then analyze their potential future impacts. In applying this step to our study, by integrating opinions and viewpoints of the panel experts, the authors have strived to outlay some plausible future directions for the three trends (SD, HE, and SD-HE) in the decade following the UN DESD.

\subsection{Sixth step: analysis of possible interactive effects between the trends}

Since the trends are interdependent, possible interactive effects in the future should not be overlooked. This step aims to investigate these interlinked effects that would lead to a better understanding of various relations of trends shaping the future dynamics. In this study, after identifying the future orientations of the trends under the influence of UN DESD in the previous step, their possible interactive effects in the future is analyzed.

\subsection{Seventh step: projection of future scenarios}

The purpose of the final step is to develop a set of plausible scenarios that tell very different stories, each which challenges our assumptions and illuminates the strategic issues facing the area under examination (in this case, universities). In essence, this is a narrowing phase in which the collected information from the previous steps is culled and refined to settle on a scenario framework. It requires testing various combinations of critical uncertainties until arriving at a framework that will serve as a strong platform for strategic conversation. Ultimately, after setting up a scenario framework, scenarios can be developed into narratives that begin in the present and end in the future. By applying this step to our study, the authors have collated the findings from the previous steps to lay out three complementary scenarios. Each depicts potential future orientations for universities in the next ten-years following the UN DESD, namely; a socially-, environmentally- and economicallyoriented university.

\section{Findings}

Using the seven-step tool described to this point, major discussion points from the expert panel at AUT have been combined with insights from the literature to explore future sustainability scenarios for universities. The following sections highlight some key findings that emerged.

\subsection{Qualitative analysis of three key trends}

The following three sections report the results of a qualitative trend analysis, conducted at the third step shown in Fig. 1. With findings compiled into Fig. 2, the authors discuss the directions of changes for the qualitative trends (HE, SD, and SD-HE) from the past into the present. 


\subsubsection{The development of HE trend}

Considering higher education as an adaptive system (Beynaghi et al., 2014) and the university as the major representative of the higher education sector, the authors adopt an evolutionary perspective of this institution, and examine various key factors and triggers in its development. The bottom level of Fig. 2 (Development of HE) indicates that universities have always been influenced and shaped by societal forces, needs and a series of long-term environmental factors (Denman, 2009; Martin, 2012; Stephens and Graham, 2010). These have triggered sea changes, stretching over five periods. On one hand, these range from elite "ivory tower" model universities until the 1950s, and on the other to a recent evolution into entrepreneurial universities and functions such as technology transfer, which have emerged since the 1990s in reaction to an increasingly knowledge-driven economy (Etzkowitz et al., 2000; Trencher et al., 2014a). In each period, universities have faced different issues and consequently formulated unique responses, which are observable in their visions, missions, strategies and plans (Peterson, 1999). Despite the fundamental evolutions observable in the form and function of sustainable development during this six-decade period, a general trend gathering steam since the 1970s is an increasing pressure for universities and scientists to address the needs of society, and particularly those related to advancing sustainable development (Crow, 2010). This shift in attention from the elite class to society at large has also been famously articulated through the idea of a "new social contract" for science (Gibbons, 1999; Lubchenco, 1998). It has also been framed through the notion of a so-called "third mission" for responding to societal interests such as economic and social development (Vorley and Nelles, 2008). Projecting this trend into the future, the authors perceive the long-term goal of universities in the following decade and beyond to be increasingly that of advancing science and education that serves society; a goal that will demand increased attention to the nature of societal needs.

\subsubsection{The evolution of SD trend}

Taking sustainable development as an ongoing stream, the top-level of Fig. 2 (Evolution of SD) similarly depicts the evolution of the concept of "sustainable development" during four decades extending from Rio-20 (UNCHE) in 1972 to Riop20 in 2012. The authors bring attention to a significant shift that has occurred, from a concept centered on the "human environment" (i.e. the natural environment and environmental conservation as pre-requisites for a healthy life and human survival), then to "environment and development" (i.e. inappropriate patterns of development as the most detrimental factor to the environment) and more recently to "sustainable development", which strives to resolve tensions between calls for economic growth and environmental preservation through a holistic framing of all three dimensions (i.e. environment, economy and society) of sustainability ${ }^{3}$ (Morse, 2010). As another way of articulating this evolution, the authors argue that during this period the concept of sustainable development has shifted in focus from "environmental well-being" to "sustainable well-being".

\subsubsection{The advancement of SD-HE trend}

A core message of Fig. 2 is that the combination of evolving notions of sustainable development (the top row Evolution of SD) on one hand, and broader structural transformations in response to societal changes on the other hand (the bottom row Development of HE) are combining to affect the extent and nature by which sustainable development has been integrated by higher education. This is depicted as a merging of these two trends in the middle level (Advancement of SD-HE). This advancement is categorized into three interrelated phases:

Phase 1: A new attitude in HE toward SD

The emerging concept of sustainable development prompted a superficial "acknowledgement" response in some institutions during the 1970s and 80 s. This corresponds to what Sterling and Thomas (2006) refer to as a "weak" or "bolton" response. Although sustainable development did not succeed in affecting all universities, it nevertheless settled into the vision of several frontrunner institutions (Calder and Clugston, 2003). Responses mostly entailed the holding of conferences or publication of studies related to sustainable development, and in engineering and physical sciences, efforts to address environmental issues through technological development.

Phase 2: Sustainability in HE

In the "Sustainability in HEoo phase, continued integration of the sustainable development paradigm into universities has provided a breeding ground for embedding sustainability in HE through various methods (Lozano et al., 2013a, 2014) such as conferences, official statements and declarations, charters and initiatives (shown in Table 2) and importantly, the incorporation of sustainability into curriculums. ${ }^{4}$ Needless to say, the UN DESD has proved a major driver of global efforts to tie sustainability knowledge and thinking with education (Tilbury, 2011; Leal Filho and Brandli, 2016). This phase corresponds with a "build-in" stage (Sterling and Thomas, 2006) which has, in parallel, prompted the green campus movement and establishment of offices, centers and departments dealing with SD (Leal Filho, 2010, 2011a).

\section{Phase 3: HE for SD}

More recently, Fig. 2 shows that the relation between sustainable development and higher education, represented by several frontrunner universities around the world, has now entered into a third phase "HE for SD". Here, sustainable development has become deeply integrated into the structure and mission of the university to the point of prompting, in some areas and activities, a "rebuild" or "redesign" type response (Sterling and

Thomas, 2006). As a key characteristic of this phase, collaborations with external stakeholders have become an essential element to the knowledge production process for sustainable development (Mauser et al., 2013; Trencher et al., 2014b; Zilahy and Huisingh, 2009). Technology transfer, entrepreneurialism, societal interventions and the co-creation of tools and experiments to drive societal transformations towards sustainability are becoming more and more significant areas of activity, in addition to established missions of research and education (Trencher et al., 2014a). Efforts to materialize sustainable development are therefore 
becoming increasingly focused off-campus and on the surrounding society (Mero, 2011). Also, in some frontrunner institutions, ambitions to steer neighboring regions and communities towards greater sustainability through multi-stakeholder partnerships have been elevated to an explicitly stated institutional priority or mission (Beynaghi et al., 2014; Trencher et al., 2014a). Furthermore, increasing tendencies to pursue sustainable development in tandem with societal stakeholders are generating emerging opportunities to integrate students into experiential learning approaches and the co-creation of knowledge and tools for spurring advancing sustainable development in local communities and regions (Rosenberg Daneri et al., 2015; Trencher et al., 2015). Of importance, the mid-term review of the UN DESD has highlighted that stakeholder collaborations and experiential approaches are particularly conducive to effective ESD (Tilbury, 2011). The authors therefore perceive this trajectory of the SD-HE trend as a major shaper of the structure and function of university education over the next decade.

4.2. Projection of future direction of the trends under the influence of a potential second UN DESD

According to the integrated opinions and viewpoints of the panel experts, conducted at the fifth step, the following changes would be expected for the three trends discussed above if considering a second UN DESD as a driving force and major global policy in the post Riop20 and post-2015 SDGs process: As mentioned, the SD trend has gradually expanded and evolved from a onedimensional to a multi-dimensional concept, now encompassing a wide range of thematic areas outlined by "The Future We Want" (see Table 3). It is expected that the SD trend, guided by discussions and policies from a second UN DESD, would enter into a new (fourth) phase of "post sustainability" in which not only development, but every aspect of society, should be sustainable.

Regarding the SD-HE trend, evolving and expanding conceptions of sustainable development (i.e. from an environmental focus to all aspects of development) would continue shaping practices of ESD. This would occur as expanded notions of sustainable development allow the integration of sustainability into a wider array of subject areas, disciplines and universities than an environmentally-focused conception. This broadening will continue, thereby allowing more and more universities to integrate sustainability into education, leading to the reinforcement of SD-HE.
As for the HE trend, it is expected that universities once again will experience a paradigm shift and fundamental changes in their structure, role and mission, and enter into a new (sixth) period "universities and sustainable development". During this period, HE for SD would constitute one of their most important missions. This view corresponds with arguments of other scholars who also envision the pursuit of sustainable development as an increasingly core "mission" for the university of tomorrow (Culum et al., 2013).

\subsection{Future scenarios}

As mentioned, many universities under the influence of an expanding sustainable development trend are entering into a new era. Fundamental changes in the structure, functions and societal roles of universities are therefore expected for the future. Considering the facilitative role of UN DESD in driving these possible changes in accord with "The Future We Want" and commitments outlined in the post-2015 SDGs, the authors have conceptualized and examined three complementary scenarios (socially-, environmentally-, and economicallyoriented) into Fig. 3 and Table 4. In each, "HE for SD" has become a core mission for the university over the next decade. Each scenario is unpacked in the following sections. Although Fig. 3 shows a probable overlap of these scenarios and many "hybrid" institutions, here the authors discuss each scenario in isolation for the sake of clarity and to better highlight the distinctive characteristics of each. Importantly, our individual examination of each scenario is based on the assumption that some would have more relevance for specific academic fields and departments than others. Therefore, the authors envision the so called university more so as a "multi-university" (Kerr, 2001) and that differing quarters of the university would move towards differing scenarios in accord with their contrasting strengths, priorities and conceptions of sustainable development. That said, as also shown in Fig. 3, in other universities the authors envision that one individual scenario could potentially serve as an overall guiding map, institutional identity and response to the challenge of ESD and sustainable development.

\subsubsection{The first scenario: socially-oriented universities}

As shown in Table 4, this model of university paints the portrait of a "socially engaged university" (Horrigan, 2014; Whitmer et al., 2010); an institution committed to advancing equitable and sustainable social and economic development in partnership with its surrounding community and region. This pursuit of materializing sustainability would have an overwhelming focus on social and

Key thematic areas highlighted in "The Future We Want" for action and follow-up (Based on United Nations, 2012)

\begin{tabular}{|c|c|c|}
\hline Social focus & Environmental focus & Economic focus \\
\hline Food security and nutrition & Sustainable cities and human settlements and sanitation & Green economy \\
\hline Health and population & & Poverty eradication \\
\hline Social protection & $\begin{array}{l}\text { Disaster risk reductionfi } \\
\text { Deserti cation, land degradation and drought }\end{array}$ & Promotion of productive and decent employment \\
\hline Education & Sustainable agriculture & Sustainable consumption and production \\
\hline \multirow[t]{9}{*}{$\begin{array}{l}\text { Gender equality and the empowerment of } \\
\text { women }\end{array}$} & Chemicals and waste & Sustainable tourism \\
\hline & Energy & \\
\hline & Sustainable transport & \\
\hline & Climate change & \\
\hline & Oceans and seas & \\
\hline & Forests & \\
\hline & Biodiversity & \\
\hline & Mountains & \\
\hline & Mining & \\
\hline
\end{tabular}




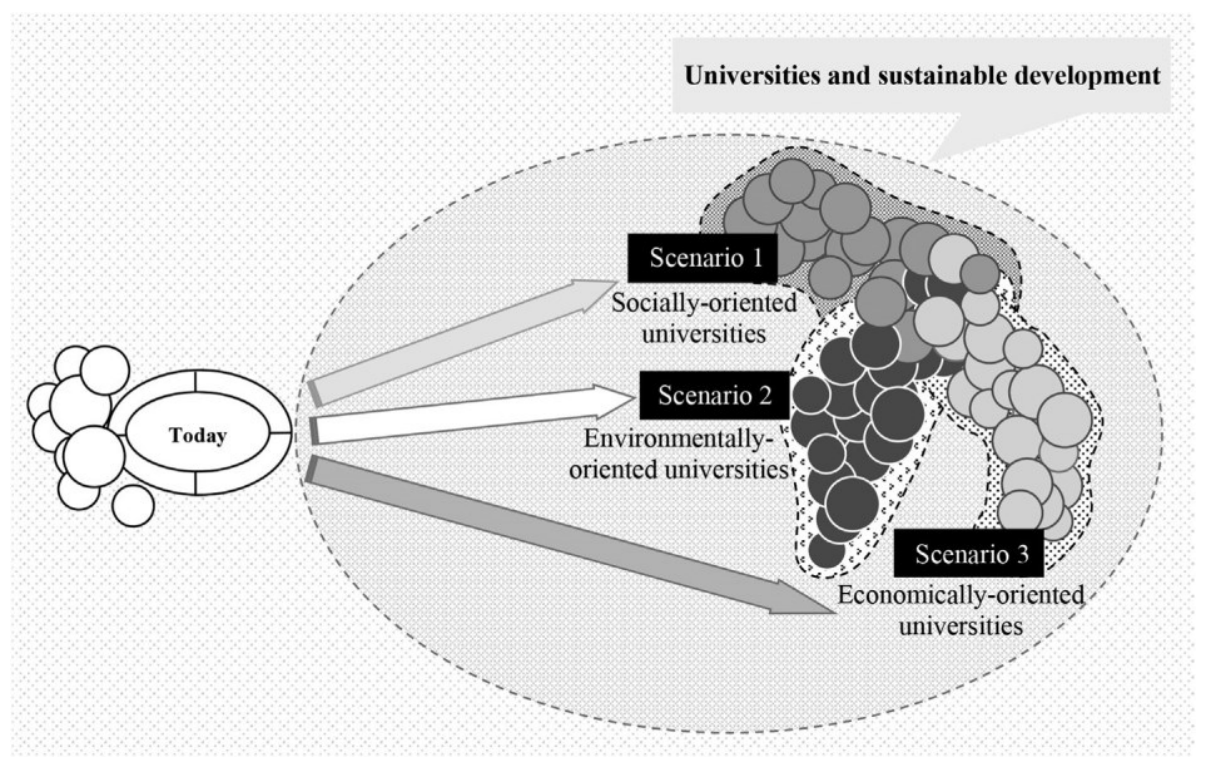

Fig. 3. Sustainability scenarios for future universities in the new era.

human development. Accordingly, the main mission of such universities would be the co-creation of societal transformations for advancing social well-being through education, research and outreach. This type of university would play a key role in tackling diverse social challenges such as food security and nutrition, public health, population (i.e. increase, decrease and aging), poverty, social protection, education, income and gender equality, and the empowerment of women (i.e. socially-focused themes highlighted in "The Future We Want" [see Table 3]). As such, ESD in this form of university would be focused on advancing sustainability related knowledge and skills through engagement on a local or regional scale. Students would be seen not as passive learners but more so as "change agents" for triggering social transformations towards sustainability (Rosenberg Daneri et al., 2015). Fields such as the humanities and social sciences (i.e. political science, public policy, psychology, sociology, and so on) would have a high relevance to such focus areas and therefore become emphasized disciplines. Additionally, this scenario would expect to see coalitions formed with municipalities, non-profit organizations (NPOs) and non-governmental organization (NGOs), local enterprises and individual citizens or groups. The numerous Regional Centers of Expertise (RCEs) formed around the world under the UN DESD also provide a valuable glimpse into this model of university rooted deeply in its surrounding community. As documented by Fadeeva et al. (2014), a core role of the RCE is to pursue sustainable development and implementation of ESD through socially-orientated collaborations with other educational institutions and societal sectors. In the socially-orientated scenario, some projects and activities that one might expect to see are, for example, the creation of grassroot urban renewal projects to facilitate citizen engagement in decisionmaking and public policy (Horrigan, 2014), creation and trials of alternative indicators of societal progress and societal well-being (Filho et al., 2015b), capacity raising of citizens (i.e. training for workplace skills) and social capital, collaboration with K-12 institutions to improve educational quality and opportunities and expand ESD, fostering of social innovation and local enterprise, and spurring of local investment and ownership to advance equitable economic development and wealth distribution (Rosenberg Daneri et al., 2015). Efforts to spur development of the social dimensions of sustainability would therefore bring the geographical focus of the university to immediate communities and regions, or specific geographical areas of developing countries. As a key example of such engagement today, the Millennium Villages project by the Earth Institute at Columbia University targets ten African countries through numerous research and development programs related to health (Singh and Sachs, 2013), food and energy (Adkins et al., 2010). In the socially-orientated university, functions such as education, research, outreach and community development would have high relevance for such roles in society. Potential impacts from socially-orientated forms of co-creation would include the generation and demonstration of new social configurations and enterprises (Rosenberg Daneri et al., 2015), advancement of the human dimensions of sustainable development such as quality of life and well-being, health, gender equality, nutrition and so on, establishment of monitoring mechanisms for social problems, improved governance of local challenges through collaboration of various societal stakeholders (Horrigan, 2014), and capacity building of local enterprises (O'Brien and Sarkis, 2014).

\subsubsection{The second scenario: environmentally-oriented universities}

Following Table 4, this scenario depicts a model of university devoted to the co-creation of strategies and tools for environmental transformations and the pursuit of sustainability through environmental improvement. Environmentally focused themes from "The Future We Want" (highlighted in Table 3) would be of high concern to this type of institution. These would include, among others, water and sanitation, disaster risk reduction, climate change, land degradation such as desertification and deforestation, sustainable agriculture, waste and pollution, renewable energy and energy efficiency, sustainable transport, biodiversity, land and marine resources and eco-systems, and the built environment. This emphasis on the physical environment would particularly bring into play fields such as the natural sciences (e.g. Earth sciences, GIS, resource management, ecology, chemistry and so on) and diverse engineering disciplines. ESD approaches in this university, being heavily focused on the physical environment, would pursue education through environmental literacy and first-hand experiences in nature (much like traditional paradigms of environmental education), and additionally, by utilizing the built and natural spaces as 
Table 4

Summery of the main points related to three sustainability scenarios.

Scenario 1: Socially-oriented universities $\quad$ Scenario 2: Environmentally-oriented universities Scenario 3: Economically-oriented universities

\begin{tabular}{|c|c|c|c|}
\hline Mission & $\begin{array}{l}\text { Co-creation of knowledge and societal } \\
\text { transformations for advancing sustainability } \\
\text { through social well-being and human development }\end{array}$ & $\begin{array}{l}\text { Co-creation of knowledge and societal } \\
\text { transformations for pursuing sustainability } \\
\text { through environmental improvements }\end{array}$ & $\begin{array}{l}\text { Co-creation of knowledge, strategies and } \\
\text { inventions for pursuing sustainability through } \\
\text { economic development and entrepreneurialism }\end{array}$ \\
\hline $\begin{array}{l}\text { Potential focus areas from } \\
\text { "The Future We Want" } \\
\text { (see Table 3) }\end{array}$ & $\begin{array}{l}\text { Food security and nutrition } \\
\text { Health and population } \\
\text { Social protection } \\
\text { Education } \\
\text { Gender equality and the empowerment of } \\
\text { women }\end{array}$ & $\begin{array}{l}\text { Sustainable cities and human } \\
\text { settlements Water and } \\
\text { sanitation } \\
\text { Disaster risk reduction } \\
\text { Desertification, land degradation and } \\
\text { drought } \\
\text { Sustainable agriculture } \\
\text { Chemicals and waste } \\
\text { Energy } \\
\text { Sustainable transport } \\
\text { Climate change } \\
\text { Oceans and seas } \\
\text { Forests } \\
\text { Biodiversity } \\
\text { Mountains }\end{array}$ & $\begin{array}{l}\text { Poverty eradication } \\
\text { Promotion of productive and } \\
\text { decent employment Sustainable } \\
\text { consumption and production } \\
\text { Sustainable tourism }\end{array}$ \\
\hline Emphasized disciplines & $\begin{array}{l}\text { Social sciences (political science, } \\
\text { sociology, etc.) } \\
\text { Humanities }\end{array}$ & $\begin{array}{l}\text { Mining } \\
\text { Natural sciences (Earth sciences, GIS, ecology, } \\
\text { resource management etc.) } \\
\text { Engineering }\end{array}$ & $\begin{array}{l}\text { Social sciences (economics, business } \\
\text { management, community development etc.) } \\
\text { Natural sciences (biotechnology, } \\
\text { IT, engineering etc.) }\end{array}$ \\
\hline View of ESD & $\begin{array}{l}\text { Education through engagement on local or regional } \\
\text { scale to varied social issues Students as "change } \\
\text { agents" for triggering social transformations } \\
\text { towards sustainability }\end{array}$ & $\begin{array}{l}\text { Education through environmental } \\
\text { literacy and first-hand experiences in } \\
\text { nature } \\
\text { The human and natural environment as a } \\
\text { "living laboratory" for sustainability learning }\end{array}$ & $\begin{array}{l}\text { Education through active industry } \\
\text { co-operation and fostering of } \\
\text { entrepreneurialism and economic } \\
\text { potential Students as "human } \\
\text { capital" for the economy }\end{array}$ \\
\hline Potential core partners & $\begin{array}{l}\text { Civil society } \\
\text { NPOs and NGOs } \\
\text { Municipalities } \\
\text { Local enterprises }\end{array}$ & $\begin{array}{l}\text { Government research laboratories } \\
\text { Municipalities } \\
\text { Industry } \\
\text { NGOs and NPOs } \\
\text { Decision making and visualization }\end{array}$ & $\begin{array}{l}\text { Medium to large industry } \\
\text { Economic development organizations } \\
\text { Municipalities and state government }\end{array}$ \\
\hline $\begin{array}{l}\text { Potential projects/ } \\
\text { activities/outputs with } \\
\text { external stakeholders }\end{array}$ & $\begin{array}{l}\text { Fostering of citizen engagement in } \\
\text { public policy shaping Capacity raising } \\
\text { of citizens Improvement of educational } \\
\text { quality and opportunities Fostering of } \\
\text { social } \\
\text { innovation and local enterprise } \\
\text { Fostering of local investment and ownership }\end{array}$ & $\begin{array}{l}\text { tools } \\
\text { Environmental monitoring and } \\
\text { projections } \\
\text { Environmental restoration } \\
\text { Scientific advisory Technological } \\
\text { innovation and technology transfer } \\
\text { Living laboratories for trialing } \\
\text { emerging technologies } \\
\text { Green buildings and campus } \\
\text { Local or regional }\end{array}$ & $\begin{array}{l}\text { Technology transfer } \\
\text { Spin-off firm creation } \\
\text { Green technology parks and university-industry } \\
\text { R\&D facilities } \\
\text { Consulting/training to industry } \\
\text { Workforce development Local and } \\
\text { regional economic development } \\
\text { through strategic purchasing and } \\
\text { real estate development } \\
\text { Joint teaching with industry }\end{array}$ \\
\hline Geographical focus & $\begin{array}{l}\text { Local or regional } \\
\text { Developing countries }\end{array}$ & $\begin{array}{l}\text { Developing countries } \\
\text { Research }\end{array}$ & $\begin{array}{l}\text { Regional } \\
\text { National }\end{array}$ \\
\hline $\begin{array}{l}\text { Main university functions } \\
\text { concerned }\end{array}$ & $\begin{array}{l}\text { Education } \\
\text { Research } \\
\text { Outreach and community development }\end{array}$ & $\begin{array}{l}\text { Outreach } \\
\text { Transformations and improvements of }\end{array}$ & $\begin{array}{l}\text { Research } \\
\text { Technology-transfer and } \\
\text { entrepreneurialism }\end{array}$ \\
\hline Potential impacts & $\begin{array}{l}\text { Creation of new social configurations } \\
\text { Advancement of human dimensions of } \\
\text { sustainable development } \\
\text { Establishment of monitoring mechanisms for } \\
\text { social problems (such as gender equality and } \\
\text { poverty reduction) } \\
\text { Improved governance of local challenges } \\
\text { through collaboration }\end{array}$ & $\begin{array}{l}\text { environmental conditions } \\
\text { Improved environmental governance } \\
\text { Creation and trial of environmental } \\
\text { technologies Establishment of monitoring } \\
\text { and evaluation mechanisms for } \\
\text { environmental issues (such as energy } \\
\text { consumption, emissions and water-quality) } \\
\text { Generation and diffusion of fundamental } \\
\text { datasets and decision making tools to } \\
\text { inform evidence-based policy making. }\end{array}$ & $\begin{array}{l}\text { Boosting of industrial innovation Creation } \\
\text { and commercialization of new green } \\
\text { technologies } \\
\text { Generation of new venture firms, employment } \\
\text { and innovation zones Raising of regional } \\
\text { economies and international competitiveness }\end{array}$ \\
\hline
\end{tabular}

a "living laboratory" for sustainability learning (Orr and Cohen, 2013;

McCormick and Kiss, 2015; Evans and Karvonen, 2014).

Potential external partners might include various government research laboratories, municipalities, industry, NGOs and NPOs. It is envisioned that this university would engage in projects with these stakeholders such as environmental monitoring and restoration, scientific advisory, trials of emerging technological innovation through living laboratories for renewable energies (Peer and Stoeglehner, 2013), green transport, buildings (Evans and Karvonen, 2011; 
Trencher et al., 2014a) and urban infrastructure, to name a few potential pathways. Such activities would therefore demand a local or regional focus, although they might also potentially extend to collaborative efforts to improve environmental and living conditions in developing countries such as Africa (Oswald and Schenker, 2010). The environmental focus of this university would bring into play the research and outreach function of the university in particular. Potential impacts that could be expected from environmentally-oriented universities would be diverse. They might include, for example, transformations and improvements of environmental conditions in the built and natural environment through technical innovation or green building construction (both on-an off-campus) (Orr and Cohen, 2013); forging of new environmental governance networks; development, demonstration and diffusion of new or emerging environmental technologies such as smart grids (Wigg et al., 2013); establishment of monitoring and evaluation mechanisms for environmental indicators such as energy consumption, GHG emissions, carbon sequestration and water-quality, and lastly, generation and diffusion of fundamental datasets and decision making tools to inform evidence-based policy making (Evans and Karvonen, 2014).

\subsubsection{The third scenario: economically-oriented universities}

This university would be expected to emerge in pursuit of sustainability through economic development and entrepreneurialism. This is already a widely normalized and promoted pathway for the university, as suggested by framings of a "third-mission" (Trencher et al., 2014a; Vorley and Nelles, 2008) or "entrepreneurial university" (Etzkowitz et al., 2000; Etzkowitz, 2002). In this paradigm, institutions historically pro-active in technologytransfer to industry and spin-off creation such as MIT and Stanford have become the global yardstick par excellence for a socially engaged university. Although the overwhelming focus to date in such institutions has been on the economy rather than sustainability, conceptually at least, some argue that pursuit of sustainability and green development is feasible and even desirable as an institutional mission (Carayannis and Campbell, 2010; Etzkowitz and Zhou, 2006). The integration of sustainable development values and environmental concerns with conventional entrepreneurial paradigms thus constitutes the defining characteristic of this scenario.

With the main mission of the university on the co-creation of knowledge, strategies and tools for advancing sustainability through economicallyorientated activities, thematic focuses of research, education and societal interactions could concern areas such as, for example, the materialization of a green and knowledgedriven economy, business development and fostering of new forms of enterprise and economic activity, community development, poverty alleviation, employment creation, sustainable consumption and production, and sustainable tourism. This would generate opportunities for substantial activation of disciplines encompassing both the social sciences (economics, business management, public policy, community development, and so on) and the hard sciences (IT, biotechnology, engineering, and so on), where entrepreneurialism, technology-transfer and university-industry linkages are today most concentrated (Mowery, 2007). ESD in this university would occur largely through active industry cooperation and the fostering of entrepreneurialism and economic potential of students. This would correspond to views from OECD "regional engagement" literature where students are framed as "human capital" for the economy (OECD, 2007). This university would likely work collaboratively with external partners such as medium to large industry, economic development organizations, municipalities and state government in an array of economicallycentered activities such as technology transfer through patenting and licensing of academic inventions, collaborative product design and household trials with industry and citizens (Liedtke et al., 2012), spin-off firm creation, establishment of green technology parks (McCauley and Stephens, 2012) and university-industry research and development (R\&D) facilities, consulting and training to industry, workforce development, local and regional economic development through strategic purchasing, and potentially even green real estate development (Orr and Cohen, 2013). As such, the research and technology-transfer/entrepreneurial function of the university would be highly emphasized. The geographical focus of this institution, being more so on markets and economic systems than specific communities, would be on the regional and national scale. Potential impacts to be expected from this type of institution could include: boosting of industrial innovation (Mowery, 2007) through creation, trial and commercialization of new green technologies for accelerating the transition to a low-carbon economy; generation of new venture firms, employment and innovation zones and R\&D facilities for universityindustry collaboration (Philpott et al., 2011) and raising of regional economies and international competitiveness (OECD, 2007).

\section{Policy measures for achieving individual scenarios}

Section 4.3 has presented three highly contrastingdyet potentially complimentarydscenarios for the university over the next decade as further responses are taken to integrate sustainable development into its various functions. This description of three possible futures is an important step in gaining insight into future pathways for the university in response to the ongoing challenge of continuing implementation of ESD into the next decade. However, further analysis on the types of conditions and policies required to nudge a university in any of these directions will increase the utility of these scenarios. This section draws on insights from various literature to generate hints for government policy makers (external measures) and university decision makers (internal measures) on the types of policies and incentives that might encourage a university to pursue either, or a combination, of these pathways.

\subsection{Policies for promoting socially-oriented universities}

Beginning with external measures that government decision makers could take to encourage universities to respond to ESD and sustainability in a sociallyorientated manner, signals need to be sent to universities and faculty that societal engagement is valued and desired (Whitmer et al., 2010). One way such a message could be sent is through university performance appraisal systems, which have a large potential to influence university behavior in a desired direction (Fadeeva and Mochizuki, 2010; Yarime and Tanaka, 2012). As one example, the UK Research Excellence Framework (UK-REF) demonstrates the possibility of allocating competitive research funds based on impacts to the wider economy and society (Parker and van Teijlingen, 2012). In this evaluation scheme, self-reported societal impacts from university research are weighted as $20 \%$ for societal and economic impacts, in addition to $65 \%$ for conventional research outputs and $15 \%$ for the quality of research environments, which also encompasses collaborations with external stakeholders. Importantly, the share of the "impacts" score is set to increase in coming years. Although this pioneering attempt to make universities accountable for their social impacts has provoked some resistance (Martin, 2011), this initiative suggests that other countries too could experiment with the integration of societal impact measures into the allocation of competitive research funds. A second approach to encouraging universities to become sociallyorientated and engaged could occur through government funding systems. If government funding programmes were to stipulate socially-orientated themes for research and engagement with external stakeholders, surrounding communities and regions (Dedeurwaerdere, 2013), this could prove a driving force in encouraging universities to purse sustainability and ESD from a socially-orientated pathway.

In parallel, internal measures taken from within the university could also play a key role in pushing universities in a particular direction. Conventional university incentive and reward systems are heavily weighted towards outputs such as publications, conference presentations and researchdand not the societal impact or utility of this activity (Dedeurwaerdere, 2013). This is frequently cited as a barrier for the promotion of faculty engagement to sustainability and local or place-based challenges (Trencher et al., 2014b; Whitmer et al., 2010; Yarime et al., 2012). Universities and departments could therefore take into account societal engagements and impacts along with conventional outputs when evaluating faculty performance for tenure. This commitment to fostering societal 
engagement could be made explicit in either university- or department-level policies. Further, the alignment of education, research and outreach with local needs is vital for authentic social engagement (Horrigan, 2014). Universities could take pro-active measures in this regard by supporting existing, or establishing new, infrastructure such as community outreach centers for fostering faculty and community collaboration through research and for facilitating experiential, collaborative and communitybased learning opportunities for students via internships and problem-based learning (Rosenberg Daneri et al., 2015; O'Brien and Sarkis, 2014).

\subsection{Policies for promoting environmentally-oriented universities}

Beginning with external measures that government decision makers could take to entice universities to head down an environmentally-orientated path, once again, the abovementioned UK-REF demonstrates that national governments could also allocate performance based research funds according to contributions to the environment. Concretely, UK-REF indicators developed to measure environmental impacts of research in various engineering and natural science fields include, for example, environmental improvement through the "introduction of new, or the improvement of existing product(s), process(es)"; influence on "policy debate on the environment, environmental policy decisions or planning decisions"; improvements in "management or conservation of natural resources, including energy, water and food"; and also, measures leading to a "reduction in carbon dioxide or other environmentally damaging emissions" (Parker and van Teijlingen, 2012). If university departments accepting federal research funds were required to demonstrate environmental impacts of research with similar indicators, they would have a larger incentive to tie research agendas to the needs and conditions of specific geographical locations and make extra efforts to increase the practical value of research.

As for internal measures to promote an environmentallyorientated university, as argued by countless scholars (Alshuwaikhat and Abubakar, 2008; Koester et al., 2006; Evans et al., 2015), the campus itself represents a ripe occasion for the university to demonstrate environmental sustainability and innovation. With universities increasingly positioning their campuses, buildings and real estate assets as "living laboratories" (Evans and Karvonen, 2014), institutions can further the progress attained over the last decade or so in the global shift towards green campuses. With many institutions committing to aggressive GHG reduction targetsdor even climate neutralitydfurther progress can be made in green construction (both new and retrofitting), sustainable purchasing, integration of renewable energies or lowcarbon transport systems, and measures to improve ecological health of campuses. Such efforts can permeate into the local community, where university-led urban reform can function as a driver of green building innovation and environmental improvements (Evans and Karvonen, 2014; Orr and Cohen, 2013). Further, such efforts can also generate diverse opportunities for students and faculty to exploit urban environmental transformations processes as platforms for experiential and project-based sustainability education (Rosenberg Daneri et al., 2015; Horrigan, 2014; McCormick and Kiss, 2015). A worldwide propagation of sustainability ranking systems (Yarime and Tanaka, 2012) suggests also that universities could be coaxed into elevating such activities to institutional priorities if on-campus sustainability measurements were integrated into conventional government appraisal systems, which are typically focused on gauging research excellence through indicators such as numbers of publications, citations, patents and journal impact factors.

\subsection{Policies for promoting economically-oriented universities}

Starting with the renowned Bayh-Dole Act of 1980 in the U.S. (Mowery, 2007), governments around the world are already proactively taking various measures to encourage universities to forge closer industrial ties and harness their resources to the goal of driving economic growth (OECD, 2007). The challenge in materializing this scenario is therefore in bringing universities to appreciate that economic contributions alone are not sufficient for materializing sustainable development, and to encourage the integration of sustainability and environmental concerns into entrepreneurialism and economically-orientated activities. One potential measure could be that which is presently underway in Singapore. Here the National Research Foundation has financed construction of a technology park at the National University of Singapore called Campus for Research Excellence and Technological Enterprise (CREATE). With an explicit focus on green technology, this provides the physical infrastructure for academics and industrial partners to engage in the co-creation of new technologies for hastening the nation's shift to a low-carbon economy (Trencher and Bai, in press). Although such strategies would not suit all national circumstances and budgets, governments could privilege university-industry collaborations that tackle sustainability related issues in their allocation of funding support. They could also shift their expectations regarding university-industry exchanges from traditional "hard" outcomes such as patents, licenses and technological prototypes (Philpott et al., 2011) to "softer" forms of industry exchange and economic activity that would also compliment ESD implementation such as internships (Domask, 2007), student consulting to industry (O'Brien and Sarkis, 2014) and collaborative teaching.

Regarding internal measures to push universities in this direction, active entrepreneurial universities around the world currently offer various incentives to faculty to encourage commercialization of research outcomes. Some approaches include offering start-up funds and venture creation support through business competitions (Gibb et al., 2013), allowing or encouraging faculty consulting, and also, institutional or departmental recognition of collaborations with industry, especially those bringing in research funds. Universities could encourage relations with industry and entrepreneurial activities linked to the advancement of sustainability by privileging the commercialization of low-carbon technologies and services with financial support, or by making such priorities clear in university policy. However, with most entrepreneurial activity strongly identified with the research function of the university, other measures would need to be taken to tie industry interactions with education. This is not to mention the need to encourage integration of ESD into traditionally more economically-orientated areas of the university such as business development and economics. The launch of inter- or trans-disciplinary research and educational institutes combining sustainability with economic logic and entrepreneurialism, together with active flows and exchanges of faculty, students and industry personnel, could be another means of encouraging a shift towards this model of university.

\section{Conclusions}

In pursuit of a sustainable and harmonious world through ESD, the Riop20 conference reiterated that the UN DESD should continue after completion of the initial decade 2005e2014. Support for an ongoing global pursuit of sustainable development through education has also been affirmed in the SDGs (United Nations, 2015). An open question is how implementation of this new global policy might bring about changes in universities during the next decade, that is, from 2015 to 2024 , which was the starting point of this research. A new scenario development process was proposed to systematically provide a compelling answer to this question.

The various futures for universities outlined in this research have addressed the tendency of existing scholarship to overlook sustainable development as a critical driver of changes in universities. In the few studies that have focused on sustainable development, they have not paid due attention to how changing forms of university interactions with society might spell out for both the future of ESD, and the role and structure of the university itself.

Findings from the first phase of the scenario building tool revealed that universities are entering into a new era, "universities and sustainable development". Here, the pursuit of HE for SD through societal collaborations is increasingly constituting one of their most significant missions. In the second phase, three scenarios were generated to shed more light on what 
might be, or could be, the shape and role that future universities might take during the next ten-years of this era, reaching up to 2024. Three potential models of university were envisioned; a socially-, environmentally-, and economically-oriented institution. According to these contrasting yet potentially complementary scenarios, universities will continue to undergo dramatic changes as they apply their resources to the co-creation of a sustainable society. These changes would concern their mission, focus areas, emphasized disciplines, view of ESD, core external partners, key projects, activities and outputs with societal stakeholders, geographical focus, and main functions involved. Although the authors examined each of these three scenarios in isolation, the authors envision that some types of "hybrid" university would emerge, moving towards more than one scenario in accord with the differing strengths, priorities and activities of various disciplines and departments. For other universities, an individual scenario could serve as a guiding vision for the entire institution as it worked to apply its strengths and resources to the challenge of working with society to advance sustainable development through education, research and outreach.

Future research could investigate further and evaluate the effectiveness of different political strategies for guiding multiple universities in a particular region or nation to pursue one or more, or even particular characteristics, of the three scenarios envisioned. In addition, the future scenario generating approach of this study also harbors potential utility for universities which now wish to engage in the sustainability debate. Various internal change agents and decision makers could develop a roadmap based on their vision, long term goals, and circumstances to chart specific and target-based measures by which each university might edge closer to one or more of these scenarios. In this way, the scenarios could serve as a backcasting approach for guiding the university into the next decade in a direction aligned with its particular strengths and priorities, and the needs and conditions of the surrounding society.

The authors anticipate that this study could encourage scholars and university staff, as well as political leaders, to consider how to pursue continued global efforts to motivate universities to expand ESD activities whilst increasing contributions to social, economic and environmental development.

\section{Acknowledgments}

We wish to thank all participants in the panel discussion for sharing their valuable experiences and contributing to this research. We would also like to thank the anonymous reviewers for their time and helpful comments, without which we could not have improved this manuscript.

\section{References}

Adkins, E., Eapen, S., Kaluwile, F., Nair, G., Modi, V., 2010. Off-grid energy services for the poor: introducing LED lighting in the Millennium Villages Project in Malawi. Energy Policy 38, $1087 \mathrm{e} 1097$.

Alshuwaikhat, H.M., Abubakar, I., 2008. An integrated approach to achieving campus sustainability: assessment of the current campus environmental management practices. J. Clean. Prod. 16, 1777e1785.

Amatariyakul, W., Tesaputa, K., 2009. Scenarios of Rajamangala University of Technology Isan in the next decade. Soc. Sci. 4, 402e406.

Amer, M., Daim, T.U., Jetter, A., 2013. A review of scenario planning. Futures 46, 23 e40.

Avila, R., Leger, N., 2005. The Future of Higher Education: a Scenario Evaluation of its Prospects and Challenges. iUniverse, New York, NY.

Azman, N., Sirat, M., Karim, M.A., 2010. Building future scenarios for Malaysian universities. J. Asian Public Policy 3, 86e99.

Barth, M., Adomssent, M., Albrecht, P., Burandt, S., Godemann, J., Franz-Balsen, A., Rieckmann, M., 2011. Towards a "Sustainable University": scenarios for a sustainable university development. Int. J. Innov. Sustain. Dev. 5, 313.

Beynaghi, A., Moztarzadeh, F., Maknoon, R., Waas, T., Mozafari, M., Huge, J., Leal Filho, W., 2014. Towards an orientation of higher education in the post Riop20 process: how is the game changing? Futures $63,49 \mathrm{e} 67$.

Bishop, P., Hines, A., Collins, T., 2007. The current state of scenario development: an overview of techniques. Foresight-The J. future Stud. Strat. Think. Policy 9, 5e25.

Blass, E., Jasman, A., Shelley, S., 2010. Visioning 2035: the future of the higher education sector in the UK. Futures 42, 445e453.
Boer, H., Huisman, J., Klemperer, A., Meulen, B., Neave, G., Theisens, H., Wende, M., 2002. Academia in the 21st Century: an Analysis of Trends and Perspectives in Higher Education and Research. Adviesraad voor het Wetenschaps-en Technologiebeleid.

Bo€rjeson, L., Ho€jer, M., Dreborg, K.-H., Ekvall, T., Finnveden, G., 2006. Scenario types and techniques: towards a user's guide. Futures $38,723 \mathrm{e} 739$.

Bradfield, R., Wright, G., Burt, G., Cairns, G., Van Der Heijden, K., 2005. The origins and evolution of scenario techniques in long range business planning. Futures $37,795 \mathrm{e} 812$.

Calder, W., Clugston, R.M., 2003. International efforts to promote higher education for sustainable development. Plan. High. Educ. 31, 30e44.

Carayannis, E., Campbell, D., 2010. Triple Helix, Quadruple Helix and Quintuple Helix and how do knowledge, innovation and the environment relate to each other? A proposed framework for a trans-disciplinary analysis of sustainable development and social ecology. Int. J. Soc. Ecol. Sustain. Dev. (IJSESD) 1, 41e69. Conway, M., 2003. Scenarios and university planning. J. Institutional Res. 12,34 .

Crow, M.M., 2010. Organizing teaching and research to address the grand challenges of sustainable development. BioScience 60, 488e489.

Culum, B., Roncevic, N., Ledic, J., 2013. Facing new expectationsdintegrating third mission activities into the university. In: Kehm, B., Teichler, U. (Eds.), The Academic Profession in Europe: New Tasks and New Challenges. Springer, Netherlands, pp. 163e195.

de Vries, B.J.M., Petersen, A.C., 2009. Conceptualizing sustainable development: an assessment methodology connecting values, knowledge, worldviews and scenarios. Ecol. Econ. 68, $1006 \mathrm{e} 1019$.

Dedeurwaerdere, T., 2013. Transdisciplinary sustainability science at higher education institutions: science policy tools for incremental institutional change. Sustainability 5, 3783e3801.

Denman, B.D., 2009. What Is a University in the 21st Century? Higher Education Management and Policy, 17, pp. $9 \mathrm{e} 28$.

DiSano, J., 1999. Sustainable Development as a Global Trend. In: UN-FIG Conference on Land Tenure and Cadastral Infrastructures for Sustainable Development, Melbourne, Australia.

Domask, J.J., 2007. Achieving goals in higher education: an experiential approach to sustainability studies. Int. J. Sustain. High. Educ. 8, 53e68.

Duderstadt, J.J., 2012. The future of the university: a perspective from the Oort cloud. Soc. Res, Int. Q. 79, 579e600.

Etzkowitz, H., 2002. MIT and the Rise of Entrepreneurial Science. Routledge, London.

Etzkowitz, H., Zhou, C., 2006. Triple Helix twins: innovation and sustainability. Sci. Public Policy $33,77 \mathrm{e} 83$.

Etzkowitz, H., Webster, A., Gebhardt, C., Terra, B.R.C., 2000. The future of the university and the university of the future: evolution of ivory tower to entrepreneurial paradigm. Res. Policy 29, $313 \mathrm{e} 330$.

Evans, J., Karnoven, A., 2011. Living laboratories for sustainability: exploring the politics and epistemology of urban transition. In: Bulkeley, H., Castan Broto, V., Hodson, M., Marvin, S. (Eds.), Cities and Low Carbon Transitions. Routledge, New York, pp. 126e141.

Evans, J., Karvonen, A., 2014. 'Give me a laboratory and I will lower your carbon footprint!'durban laboratories and the governance of low-carbon futures. Int. J. Urban Reg. Res. 38, 413e430.

Evans, J., Jones, R., Karvonen, A., Millard, L., Wendler, J., 2015. Living labs and coproduction: university campuses as platforms for sustainability science. Curr. Opin. Environ. Sustain 16, 1 e6.

Fadeeva, Z., Mochizuki, Y., 2010. Higher education for today and tomorrow: university appraisal for diversity, innovation and change towards sustainable development. Sustain. Sci. 5, $249 \mathrm{e} 256$.

Fadeeva, Z., Payyappallimana, U., Tabucanon, M., Chhokar, K.B., 2014. Building a Resilient Future through Multistakeholder Learning and Action: ten Years of Regional Centres of Expertise on Education for Sustainable Development. United Nations University Institute for the Advenced Study of Sustainability (UNU-IAS), Tokyo.

Fink, A., Siebe, A., Kuhle, J.-P., 2004. How scenarios support strategic early warning processes. foresight $6,173 \mathrm{e} 185$

Ford, M.P., 2002. Beyond the Modern University: toward a Constructive Postmodern University. Greenwood Publishing Group.

Gibb, A., Haskins, G., Robertson, I., 2013. Leading the Entrepreneurial University: Meeting the Entrepreneurial Development Needs of Higher Education Institutions, Universities in Change. Springer, pp. 9e45.

Gibbons, M., 1999. Science's new social contract with society. Nature 402, C81eC84.

Hashimshony, R., Haina, J., 2006. Designing the University of the Future. Planning for Higher Education, 34, p. 5.

Hayes, T., 2007. Delphi study of the future of marketing of higher education. J. Bus. Res. 60, $927 \mathrm{e} 931$.

Holdren, J.P., 2008. Science and technology for sustainable well-being. Science 319 (5862), $424 \mathrm{e} 434$.

Horrigan, P., 2014. Rust to Green: cultivating resilience in the Rust Belt. In: Bose, M., Horrigan, P., Doble, C., Shipp, S.C. (Eds.), Community Matters: Service-learning in Engaged Design and Planning. Earthscan, Oxon and New York, pp. 167e186.

Hughes, N., 2013. Towards improving the relevance of scenarios for public policy questions: a proposed methodological framework for policy relevant low carbon scenarios. Technol. Forecast. Soc. Change 80, 687e698.

Inayatullah, S., 2012. University futures: Wikipedia uni, core-periphery reversed, incremental managerialism or bliss for all? On the Horizon 20, 84e91.

Inayatullah, S., Milojevic, I., 2014. Augmented reality, the Murabbi and the democratization of higher education: alternative futures of higher education in Malaysia. On the Horizon 22, $110 \mathrm{e} 126$.

Inayatullah, S., Ahmed, S., Alam, P., Davis, S., Hashemi, S., 2013. Alternative scenarios for BRAC University. On the Horizon 21, $275 \mathrm{e} 285$. 
Job, J., Sriraman, B., 2013. A framework for quality assurance in globalization of higher education: a view toward the future. Interchange $43,75 \mathrm{e} 93$.

Kahn, H., Bell, D., Wiener, A.J., 1967. The Year 2000: a Framework for Speculation on the Next 33 Years. Macmillan, New York.

Kates, R., Clark, W., Corell, R., Hall, J., Jaeger, C., Lowe, I., McCarthy, J., Schellnhuber, H., Bolin, B., Dickson, N., 2001. Environment and development. Sustainability science. Sci. (New York, NY) 292, 641.

Kerr, C., 2001. The Uses of the University. Harvard University Press.

Koester, R.J., Eflin, J., Vann, J., 2006. Greening of the campus: a whole-systems approach. J. Clean. Prod. 14, $769 \mathrm{e} 779$.

Leal Filho, W., 2010. Teaching sustainable development at university level: current trends and future needs. J. Baltic Sci. Educ. 9, $273 \mathrm{e} 284$.

Leal Filho, W., 2011a. Applied Sustainable Development: a Way Forward in Promoting Sustainable Development in Higher Education Institutions. World Trends on Education for Sustainable Development. Peter Lang Scientific Publishers, Frankfurt.

Leal Filho, W., 2011b. About the role of universities and their contribution to sustainable development. High. Educ. Policy 24, 427e438.

Leal Filho, W., 2014. The United Nations Decade of education for sustainable development: lessons learnt and needs to be met. Int. J. Sustain. High. Educ. 15 (2), 4e5.

Leal Filho, W., Brandli, L., 2016. Engaging Stakeholders in Education for Sustainable Development at University Level. Springer, Berlin.

Leal Filho, W., Muthu, N., Edwin, G., Sima, M., 2015a. Implementing Campus Greening Initiatives: Approaches, Methods and Perspectives. Springer International Publishing, Cham.

Leal Filho, W., Manolas, E., Pace, P., 2015b. The future we want: key issues on sustainable development in higher education after Rio and the UN decade of education for sustainable development. Int. J. Sustain. High. Educ. 16, 112e129. http://dx.doi.org/10.1108/IJSHE03-2014-0036.

Liedtke, C., Jolanta Welfens, M., Rohn, H., Nordmann, J., 2012. LIVING LAB: userdriven innovation for sustainability. Int. J. Sustain. High. Educ. 13 (2), $106 \mathrm{e} 118$.

Lozano, R., Lukman, R., Lozano, F.J., Huisingh, D., Lambrechts, W., 2013a. Declarations for sustainability in higher education: becoming better leaders, through addressing the university system. J. Clean. Prod. 48, 10e19.

Lozano, R., Ceulemans, K., Alonso-Almeida, M., Huisingh, D., Lozano, F.J., Waas, T., Lambrechts, W., Lukman, R., Huge, J., 2014. A review of commitment and implementation of sustainable development in higher education: results from a worldwide survey. J. Clean. Prod. http://dx.doi.org/10.1016/j.jclepro.2014.09.048.

Lubchenco, J., 1998. Entering the century of the environment: a new social contract for science Science $279,491 \mathrm{e} 497$.

Martin, B.R., 2011. The research excellence framework and the 'impact agenda': are we creating a Frankenstein monster? Res. Eval. 20, 247e254.

Martin, B.R., 2012. Are universities and university research under threat? Towards an evolutionary model of university speciation. Camb. J. Econ. bes006.

Mauser, W., Klepper, G., Rice, M., Schmalzbauer, B.S., Hackmann, H., Leemans, R., Moore, H., 2013. Transdisciplinary global change research: the co-creation of knowledge for sustainability. Curr. Opin. Environ. Sustain. 5, 420e431.

McCauley, S.M., Stephens, J.C., 2012. Green energy clusters and socio-technical transitions: analysis of a sustainable energy cluster for regional economic development in Central Massachusetts, USA. Sustain. Sci. 7, 213e225.

McCormick, K., Kiss, B., 2015. Learning through renovations for urban sustainability: the case of the Malmo€ innovation platform. Curr. Opin. Environ. Sustain. 16, 44e50.

McNay, I., 1992. Visions of Post-compulsory Education, Society for Research into Higher Education. Open University Press, Maidenhead.

Meadows, D.H., 1972. Limits to Growth: a Report to the Club of Rome. Universe Books, New York.

Mero, T., 2011. Town and gown unite. Sustain. J. Rec. 4, 169e173.

Miller, R., 2003. The Future of the Tertiary Education Sector: Scenarios for a Learning Society, a Paper Presented at the OECD/Japan Seminar (Tokyo, Japan).

Morse, S., 2010. Sustainability: a Biological Perspective. Cambridge University Press, Cambridge.

Mowery, D., 2007. University-industry research collaboration and technology transfer in the United States. In: Yusuf, S., Nabeshima, K. (Eds.), How Universities Promote Economic Growth. The World Bank, Washington DC, pp. 163e181.

Nasruddin, E., Bustami, R., Inayatullah, S., 2012. Transformative foresight: Universiti Sains Malaysia leads the way. Futures 44, 36e 45

Nowack, M., Endrikat, J., Guenther, E., 2011. Review of Delphi-based scenario studies: quality and design considerations. Technol. Forecast. Soc. Change 78, 1603e1615.

O'Brien, W., Sarkis, J., 2014. The potential of community-based sustainability projects for deep learning initiatives. J. Clean. Prod. 62, 48e61.

Organization for Economic Co-operation and Development, 2007. Higher Education and Regions: Globally Competitive, Locally Engaged. OECD Publishing, Paris.

Orr, D.W., Cohen, A., 2013. Promoting partnerships for integrated, Post-Carbon development: strategies at work in the Oberlin Project at Oberlin College. Plan. High. Educ. 41, 22.

Oswald, F., Schenker, P., 2010. NESTown: new Ethiopian sustainable town a real life experiment. ATDF J. 7. http://www.atdforum.org/IMG/pdf OswaldATDF2010. pdf.

O'Brien, F.A., 2004. Scenario planningeelessons for practice from teaching and learning. Eur. J. Oper. Res. 152, $709 \mathrm{e} 722$.

Parker, J., van Teijlingen, E., 2012. The Research Excellence Framework (REF):

assessing the impact of social work research on society. Practice 24,41 e 52.

Peer, V., Stoeglehner, G., 2013. Universities as change agents for sustainabilityeframing the role of knowledge transfer and generation in regional development processes. J. Clean. Prod. 44, 85e 95 .
Peterson, M.W., 1999. The role of institutional research: from improvement to redesign. New Dir. Institutional Res. 104, 83e103, 1999, Issue.

Phdungsilp, A., 2011. Futures studies' backcasting method used for strategic sustainable city planning. Futures 43, 707e714.

Philpott, K., Dooley, L., O'Reilly, C., Lupton, G., 2011. The entrepreneurial university: examining the underlying academic tensions. Technovation $31,161 \mathrm{e} 170$.

Pigozzi, M.J., 2010. Implementing the UN Decade of Education for Sustainable Development (DESD): achievements, open questions and strategies for the way forward. Int. Rev. Educ. $56,255 \mathrm{e} 269$.

Pillkahn, U., 2008. Using Trends and Scenarios as Tools for Strategy Development. John Wiley \& Sons, London.

Ramirez, R., Mukherjee, M., Vezzoli, S., Kramer, A.M., 2015. Scenarios as a scholarly methodology to produce "interesting research". Futures 71, 70e87.

Ritzen, J., 2006. Scenarios for Higher Education, 2020 or when Will China Invade Iran?. In: Keynote Address during the OECD Ministerial Meeting. Paris.

Rosenberg Daneri, D., Trencher, G., Peterson, J., 2015. Students as change agents in a townwide sustainability transformation: the Oberlin Project at Oberlin College. Curr. Opin Environ. Sustain. 16, 14e21.

Scearce, D., Fulton, K., Network, G.B., 2004. What if? The Art of Scenario Thinking for Nonprofits. Global Business Network, Emeryville, CA.

Schwab, K., 2013. The Global Competitiveness Report 2013e2014. World Economic Forum, Switzerland.

Singh, P., Sachs, J.D., 2013. 1 million community health workers in sub-Saharan Africa by 2015. Lancet 382, 363e365.

Snyder, D.P., 2006. From higher education to longer, fuller, further education: the coming metamorphosis of the university. On the Horizon 14, 43e61.

Stephens, S., 2011. Science or science fiction? The application of scenario techniques to the study of possible futures for learners in higher education. In: Fifth Education in a Changing Environment Conference Book 2009: Critical Voices, Critical Times. Informing Science, p. 257.

Stephens, S., 2013. Using the past to predict the future: what futures are documented for higher education? On the Horizon 21, 323e332.

Stephens, J.C., Graham, A.C., 2010. Toward an empirical research agenda for sustainability in higher education: exploring the transition management framework. J. Clean. Prod. 18, 611 e618.

Sterling, S., Thomas, I., 2006. Education for sustainability: the role of capabilities in guiding university curricula. Int. J. Innov. Sustain. Dev. 1 (4), 349e370.

Swart, R.J., Raskin, P., Robinson, J., 2004. The problem of the future: sustainability science and scenario analysis. Glob. Environ. Change 14, 137e146.

Tilbury, D., 2009. Tracking our progress a global monitoring and evaluation framework for the UN DESD. J. Educ. Sustain. Dev. 3, 189e193.

Tilbury, D., 2011. Education for Sustainable Development: an Expert Review of Processes and Learning. UNESCO, Paris, France (accessed 20.05.15.). http:// unesdoc.unesco.org/images/0019/001914/191442e pdf.

Trencher, G., Bai, X., 2015. The role of university partnerships in urban sustainability experiments: evidence from Asia. In: Brauch, H.G., Spring, U., Grin, J., Scheffran, J. (Eds.), Sustainability Transition and Sustainable Peace Handbook. Springer (in press),

Trencher, G., Yarime, M., McCormick, K.B., Doll, C.N., Kraines, S.B., 2014a. Beyond the third mission: exploring the emerging university function of co-creation for sustainability. Sci. Public Policy 41, 151e179.

Trencher, G., Bai, X., Evans, J., McCormick, K., Yarime, M., 2014b. University partnerships for co-designing and co-producing urban sustainability. Glob. Environ. Change 28, $153 \mathrm{e} 165$.

Trencher, G., Terada, T., Yarime, M., 2015. Student participation in the co-creation of knowledge and social experiments for advancing sustainability: experiences from the University of Tokyo. Curr. Opin. Environ. Sustain. 16, 56e63.

Trencher, G., Rosenberg Daneri, D., McCormick, K., Terada, T., Peterson, J., Yarime, M., Kiss, B., 2016. The role of students in the co-creation of transformational knowledge and sustainability experiments: experiences from Sweden, Japan and the USA. In: Leal Filho, W., Brandli, L. (Eds.), Engaging Stakeholders in Education for Sustainable Development at University Level. Springer, Berlin.

UNESCO, 2005a. United Nations Decade of Education for Sustainable Development (20052014): International Implementation Scheme. United Nations Educational, Scientific and Cultural Organization (UNESCO), Paris, France.

UNESCO., 2005b. The DESD at a Glance. UNESCO, Paris. http://unesdoc.unesco.org/ images/0014/001416/141629e.pdf.

United Nations, 2012. The future we want. In: Outcome document of the United Nations Conference on Sustainable Development, Rio de Janeiro, Brazil, 20e22 June available at: http://www.uncsd2012.org/content/documents/727The\% 20Future $\% 20$ We $\% 20$ Want $\% 2019 \% 20$ June $\% 201230$ pm.pdf.

United Nations, 2015. Draft Outcome Document of the United Nations Summit for the Adoption of the Post-2015 Development Agenda (accessed 22.09.15.). http://www.un.org/ga/search/view_doc.asp?symbol11/4A/69/L.85\&Lang1/4E.

Van Notten, P.W., Rotmans, J., Van Asselt, M.B., Rothman, D.S., 2003. An updated scenario typology. Futures 35, 423e443.

Varum, C.A., Melo, C., 2010. Directions in scenario planning literatureea review of the past decades. Futures 42, 355e369.

Vincent-Lancrin, S., 2006. What is changing in academic research? Trends and futures scenarios. Eur. J. Educ. 41, 169e202.

Vincent-Lancrin, S., 2004. Building futures scenarios for universities and higher education: an international approach. Policy Futur. Educ. 2, 245e263. 
Vorley, T., Nelles, J., 2008. (Re) conceptualising the academy. High. Educ. Manag. Policy 20, $1 \mathrm{e} 17$.

Waas, T., Verbruggen, A., Wright, T., 2010. University research for sustainable development: definition and characteristics explored. J. Clean. Prod. 18, 629e636.

Wals, A.E., 2014. Sustainability in higher education in the context of the UN DESD: a review of learning and institutionalization processes. J. Clean. Prod. 62, $8 \mathrm{e} 15$.

Wangel, J., 2011. Exploring social structures and agency in backcasting studies for sustainable development. Technol. Forecast. Soc. Change 78, 872e882.

Whitmer, A., Ogden, L., Lawton, J., Sturner, P., Groffman, P.M., Schneider, L., Hart, D., Halpern, B., Schlesinger, W., Raciti, S., 2010. The engaged university: providing a platform for research that transforms society. Front. Ecol. Environ. 8, 314e 321.

Wigg, R., Breen, C., Jones, K.B., 2013. The Customers' Smart Grid: Pecan Street Inc.'s Energy Internet Demonstration Project. Institute for Energy and the Environment Vermont Law School. http://www-assets.vermontlaw.edu/Assets/iee/ PecanStreetFinalReport.pdf.

Wilkinson, A., Kupers, R., 2013. Living in the Futures. Harv. Bus. Rev. 91, 118e127.

Yarime, M., Tanaka, Y., 2012. The issues and methodologies in sustainability assessment tools for higher education institutions a review of recent trends and future challenges. J. Educ. Sustain. Dev. 6, $63 \mathrm{e} 77$.

Yarime, M., Trencher, G., Mino, T., Scholz, R.W., Olsson, L., Ness, B., Frantzeskaki, N., Rotmans, J., 2012. Establishing sustainability science in higher education institutions: towards an integration of academic development, institutionalization, and stakeholder collaborations. Sustain. Sci. 7, 101e113.

Zepke, N., 2012. What of the future for academic freedom in higher education in Aotearoa New Zealand? Policy Futur. Educ. 10, $155 \mathrm{e} 164$.

Zilahy, G., Huisingh, D., 2009. The roles of academia in regional sustainability initiatives. J. Clean. Prod. 17, 1057e1066. 